\title{
Assessment of Wear Coefficients of Nuclear Zirconium Claddings Without and With Pre-Oxidation
}

\author{
Jun $\mathrm{Qu}^{1}{ }^{1}$, Kevin M. Cooley ${ }^{1}$, Austin H. Shaw ${ }^{1}$, Roger Y. Lu ${ }^{2}$, Peter J. Blau ${ }^{3}$ \\ ${ }^{1}$ Materials Science and Technology Division, Oak Ridge National Laboratory, Oak Ridge, TN \\ 37831 \\ ${ }^{2}$ Westinghouse Electric Company, 5801 Bluff Rd, Hopkins, SC 29061 \\ ${ }^{3}$ Blau Tribology Consulting, Enka, NC 28728
}

\begin{abstract}
In the cores of pressurized water nuclear reactors, water-flow induced vibration is known to cause claddings on the fuel rods to rub against their supporting grids. Such grid-to-rod-fretting (GTRF) may lead to fretting wear-through and the leakage of radioactive species. The surfaces of actual zirconium alloy claddings in a reactor are inevitably oxidized in the high-temperature pressurized water, and some claddings are even pre-oxidized. As a result, the wear process of the surface oxide film is expected to be quite different from the zirconium alloy substrate. This study attempts to measure the wear coefficients of zirconium claddings without and with pre-oxidation rubbing against grid samples using a bench-scale fretting tribometer. Results suggest that the volumetric wear coefficient of the pre-oxidized cladding is 50 to 200 times lower than that of the untreated cladding. In terms of the linear rate of wear depth, the pre-oxidized alloy wears about 15 times more slowly than the untreated cladding. Fitted with the experimentally-determined wear rates, a stage-wise GTRF engineering wear model demonstrates good agreement with inreactor experience in predicting the trend of cladding lives.
\end{abstract}

Keywords: grid-to-rod-fretting (GTRF), nuclear zirconium claddings, wear coefficient, pre-
oxidation, stage-wise wear model

\footnotetext{
* P.O. Box 2008, MS-6063, Oak Ridge, TN 37831-6063, (865) 576-9304, qujn@ornl.gov 


\section{Introduction}

Fretting wear occurs in many places, from mechanical joints to electrical connectors, and from tubes in heat exchanger sheets to the interior of metal rope. According to ASTM standard D4170 [1], fretting wear is defined as a form of wear caused by vibratory or oscillatory motion of limited amplitude characterized by the removal of finely-divided particles from the rubbing surfaces. Waterhouse and Mindlin's early work laid the modern background for fretting research. Waterhouse characterized the phenomenon and established methods for testing, and also differentiated between fretting corrosion [2] and fretting fatigue [3]. Mindlin's analysis formed the basis for understanding the mechanics of solid contact during fretting [4]. Godet's group in France, established the role of third bodies in fretting [5], and Vingsbo's group in Sweden promoted the concept of fretting maps [6]. In the U.S., Hoeppner advanced research on fretting fatigue and its test methods, mainly applied to aerospace components [7]. Fretting regimes were more recently determined using a slip index [8].

In nuclear power generation by light water reactors, the mitigation of fretting can be important. For example, coolant flow-induced vibration of clad fuel rods against their supports, called grid-to-rod-fretting (GTRF), can lead to fretting wear-through and the release of radioactive species into the coolant loop ("leakers"). GTRF wear is currently one of the main causes of fuel rod leakage in pressurized water reactors $[9,10]$. It is worth noting that the surfaces of zirconium alloy claddings in reactor cores are inevitably oxidized in the pressurized water environment at temperatures in excess of $300{ }^{\circ} \mathrm{C}[11,12]$. Some cladding surfaces are pre-treated to intentionally form a protective film containing zirconium oxides $[11,13,14]$. Therefore, the wear process of the zirconium oxide should be treated differently from that of the zirconium alloy substrate. 
Investigators at Oak Ridge National Laboratory (ORNL) have been developing a GTRF engineering wear model (EWM) that presumes three sequential stages in the wear life of the cladding [15]. The first stage ('Stage 0') is a 'pre-wear' (incubation) period where there is either no relative motion (fully clamped) or the contacts are separated by a gap. The second stage ('Stage 1') depicts the wear-through of the oxide film on the cladding. This oxide film may be pre-grown or formed during exposure. The third stage ('Stage 2') depicts wear into the Zr alloy once the oxide layer has been removed. This final stage is likely to have a higher rate of wear because rubbing occurs on the exposed alloy. It may also be affected by hydrogen embrittlement. The development and validation of the EWM requires experimental data, most importantly to determine the wear coefficients for both the oxide film (Stage 1) and the zirconium alloy (Stage 2).

This study accesses the wear coefficients of actual zirconium cladding materials without and with pre-oxidation fretting against actual zirconium grid materials using a bench-scale tribometer. Although this bench test does not simulate the actual conditions in a lightwater reactor core, results were able to train the EWM to improve prediction of the cladding life.

\section{Materials and Experimental}

In order to achieve meaningful wear coefficients, commercial zirconium alloy cladding (tubes) and grid straps were obtained from Westinghouse Electric Company, LLC. As shown in Fig. 1, the as-received cladding is a $0.91 \mathrm{~m}$ (3') long tube with a nominal outer diameter of 9.5 $\mathrm{mm}(0.374$ ") and was segmented into test samples of $\sim 50 \mathrm{~mm}$ (2”) long. The as-received strap has springs on one side and dimples on the other side, and was cut into test samples of $\sim 50 \times 50$ $\mathrm{mm}(2 ” \times 2 ")$ squares. 


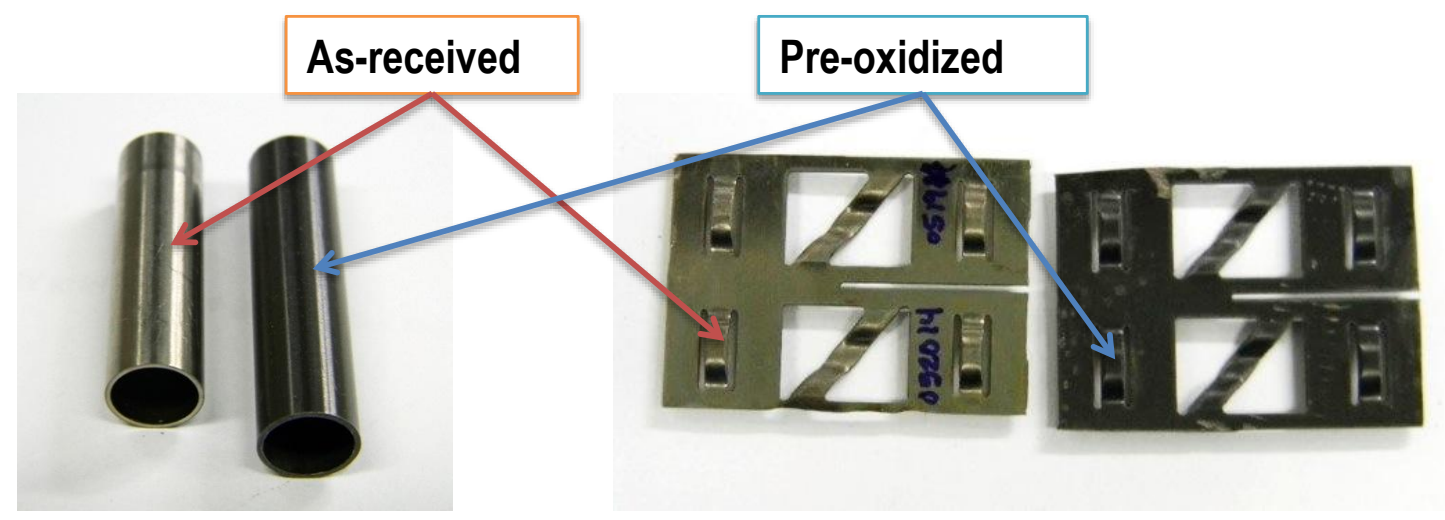

Fig. 1. Cladding and grid as-received and pre-oxidized.

In order to quantify the wear coefficient for the oxide film, a proprietary pre-oxidation process was applied to both the cladding and grid samples. The pre-oxidized surface is dark and smooth, as shown in Fig. 1. The oxide layer is 4-8 $\mu \mathrm{m}$ thick and appears to have good bonding with the substrate, as revealed by the polished cross section optical image of a pre-oxidized tube in Fig. 2. Knoop microindentation hardness was measured on the surfaces of the cladding and grid in as-received and pre-oxidized conditions using a $100 \mathrm{~g}$-f load on a Buehler Micromet® $2100^{\mathrm{TM}}$. As summarized in Table 1, the HK hardness of the as-received cladding and grid is 2.8 \pm 0.2 and 2.2 $\pm 0.3 \mathrm{GPa}$, and pre-oxidation increased the hardness of the cladding and grid to 8.8 \pm 1.0 and 5.1 $\pm 0.6 \mathrm{GPa}$, respectively. Results generally agree with the previously reported Vickers microindentation hardness for Zircaloy-4 cladding (2.45 GPa [16]) and zirconium oxide (up to $11.8 \mathrm{GPa}[17])$. 
Table 1. Knoop microindentation hardness of cladding and grid as-received and pre-oxidized.

\begin{tabular}{ccc}
\hline HK @ 100 g-f & Cladding & Grid \\
\hline As-received & $2.8^{ \pm 0.2}$ & $2.2^{ \pm 0.3}$ \\
\hline Pre-oxidized & $8.8^{ \pm 1.0}$ & $5.1^{ \pm 0.6}$ \\
\hline
\end{tabular}

A commercially-made reciprocating test machine (Ducom ${ }^{\mathrm{TM}}$ Instruments, Chicago, USA) was modified for fretting tests (Fig. 3) of the cladding and grid samples. Three major modifications were made: (1) A new cam was made to reduce the oscillation amplitude from the original $1 \mathrm{~mm}$ to $0.2 \mathrm{~mm}$ to operate closer to the actual oscillation amplitude of up to $0.1 \mathrm{~mm}$ in a nuclear reactor [11]; (2) The minimum normal force was reduced from the original $1 \mathrm{~N}$ to 0.1 N. Per Westinghouse's information, the impact forces on the cladding in a reactor are $0.05 \mathrm{~N}$ (mean) and $0.175 \mathrm{~N}$ (peak) against springs and one order of magnitude higher against dimples; and (3) Special sample holders were designed and fabricated for testing the cladding and grid samples, as shown in Fig. 3. 

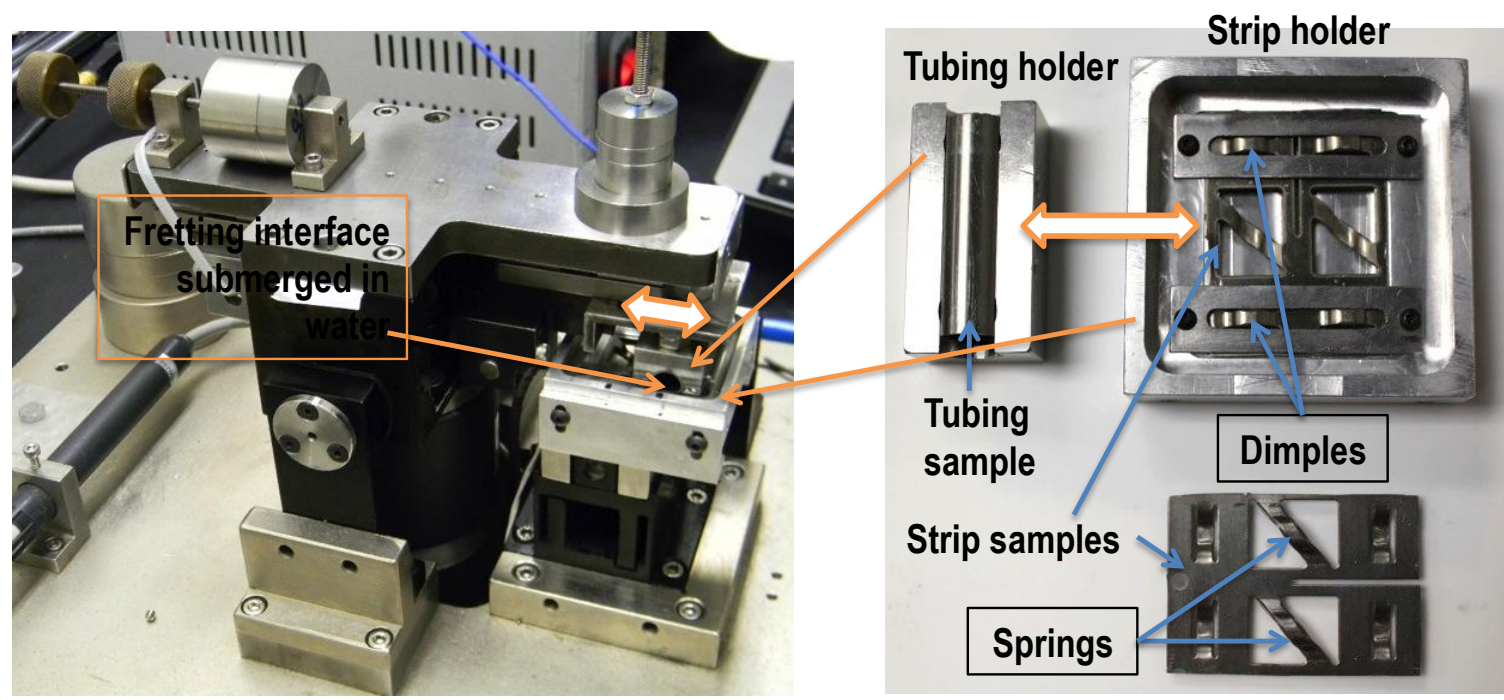

Fig. 3. Modified commercial fretting tester and sample holders for the cladding and grid samples.

The test parameters of two other GTRF simulators, the VIPER loop test at Westinghouse and the CANFRET test at AECL (Canada), are listed in Table 2, respectively (based on information in $[11,18]$ and from Westinghouse). The load, rod vibration amplitude, and oscillation frequency shown in the table are nominal values, and vary in the actual tests. For example, the measured vibration amplitude varies from 0.005 to $0.095 \mathrm{~mm}$ for rods at different locations under different water flow speeds [11].

Table 2. Parameters of VIPER tests at Westinghouse and CANFRET tests at AECL.

\begin{tabular}{|c|c|c|c|c|c|c|c|c|c|}
\hline & & $\begin{array}{l}\text { Load } \\
(\mathrm{N})\end{array}$ & $\begin{array}{l}\text { Amplitude } \\
(\mathrm{mm})\end{array}$ & $\begin{array}{l}\text { Frequency } \\
(\mathrm{Hz})\end{array}$ & $\begin{array}{l}\text { Workrate } \\
(\mathrm{mW})\end{array}$ & $\begin{array}{l}\text { Duration } \\
\text { (h) }\end{array}$ & $\begin{array}{l}\text { Work } \\
(\mathrm{mWh})\end{array}$ & $\begin{array}{l}\text { Temp } \\
\left({ }^{\circ} \mathrm{C}\right)\end{array}$ & $\begin{array}{l}\text { Pressure } \\
\text { (bar) }\end{array}$ \\
\hline \multirow[t]{2}{*}{ VIPER } & Spring & 0.1 & 0.01 & 25 & 0.05 & 500 & 25 & \multirow[t]{2}{*}{204} & \multirow[t]{2}{*}{17} \\
\hline & Dimple & 0.2 & 0.02 & 25 & 0.2 & 500 & 100 & & \\
\hline \multirow{3}{*}{$\begin{array}{l}\text { CAN- } \\
\text { FRET }\end{array}$} & Spring & 1 & 0.02 & 6.25 & 0.25 & & & \multirow{3}{*}{310} & \multirow{3}{*}{117} \\
\hline & Dimple & 4 & 0.01 & 6.25 & 0.5 & & & & \\
\hline & Grid* & $0.1-2$ & 0.03 & 15 & $0.1-2.1$ & 200 & $20-420$ & & \\
\hline
\end{tabular}

*Exact geometry not reported. 
The test matrix in this study is defined in Table 3. Note that the 'work' in the bench test is designed to match with that of the 500-hr VIPER test. The major difference is that tests here were conducted in water at ambient environment and that VIPER tests generally use pressurized flowing hot water. In each test in this study, a tube rubbed against a pair of either springs or dimples on the grid strap in the same orientation as in a nuclear reactor. Tests were conducted on both as-received and pre-oxidized samples under both a lower load (more realistic) and a higher load (accelerated). The loads were five times higher for the tests of dimples based on field experience.

Wear scar depth and wear volume were measured using a white light interferometer (Wyko NT9100), and the wear coefficient was calculated by dividing the wear volume by the work. The maximum depth for each wear scar is compared here because that is what really matters for the cladding wall life. When determining the wear volume and depth, root-mean-square curve fitting was used to fit both the worn area and adjacent unworn area (the reference surface) to compensate the roughness impact.

Table 3. Test matrix and parameters of ORNL fretting bench tests.

\begin{tabular}{|c|c|c|c|c|c|c|c|}
\hline & Material & $\begin{array}{c}\text { Load at } \\
\text { contact }(\mathrm{N})\end{array}$ & $\begin{array}{l}\text { Amplitude } \\
(\mathrm{mm})\end{array}$ & $\begin{array}{c}\text { Frequency } \\
(\mathrm{Hz})\end{array}$ & $\begin{array}{c}\text { Workrate } \\
(\mathrm{mW})\end{array}$ & $\begin{array}{l}\text { Duration } \\
\text { (h) }\end{array}$ & $\begin{array}{l}\text { Work } \\
(\mathrm{mWh})\end{array}$ \\
\hline \multirow{4}{*}{$\begin{array}{l}\text { Tube } \\
\text { against a } \\
\text { pair of } \\
\text { Springs }\end{array}$} & \multirow{2}{*}{$\begin{array}{c}\text { As- } \\
\text { received }\end{array}$} & 0.1 & 0.2 & 25 & 1 & 25 & 25 \\
\hline & & 0.5 & 0.2 & 25 & 5 & 5 & 25 \\
\hline & \multirow{2}{*}{$\begin{array}{c}\text { Pre- } \\
\text { oxidized }\end{array}$} & 0.1 & 0.2 & 25 & 1 & 25 & 25 \\
\hline & & 0.5 & 0.2 & 25 & 5 & 5 & 25 \\
\hline \multirow{4}{*}{$\begin{array}{l}\text { Tube } \\
\text { against a } \\
\text { pair of } \\
\text { Dimples }\end{array}$} & \multirow{2}{*}{$\begin{array}{c}\text { As- } \\
\text { received }\end{array}$} & 0.5 & 0.2 & 25 & 5 & 20 & 100 \\
\hline & & 2.5 & 0.2 & 25 & 25 & 4 & 100 \\
\hline & \multirow{2}{*}{$\begin{array}{c}\text { Pre- } \\
\text { oxidized }\end{array}$} & 0.5 & 0.2 & 25 & 5 & 20 & 100 \\
\hline & & 2.5 & 0.2 & 25 & 25 & 4 & 100 \\
\hline
\end{tabular}




\section{Experimental Results}

The tube wear results are summarized in Tables 4-7. Pre-oxidization effectively reduced the wear by $\sim 15$ times in terms of the scar depth and 50 to 200 times in terms of the wear coefficient.

Selected cladding wear data from the literature are listed in Table 8. A higher pre-load in the AECL assembly seems to decrease the wear coefficient because of the reduced relative motion between the grid and rod [18]. In contrast, in the current work, a higher load increases the wear coefficient of a cladding in as-received condition when rubbed against either the springs or the dimples. The current wear results of as-received tubes at the lower loads, 0.1 and $0.5 \mathrm{~N}$ against springs (Tables 4 and 5) and $0.5 \mathrm{~N}$ against dimples (Table 6), showed relatively good agreement with the literature data in Table 8. However, the wear depth and volumetric wear coefficient resulting from a load of $2.5 \mathrm{~N}$ are out of the range, and thus are not recommended for model development and validation. For the Dongguk assembly [10], the type-B spring is similar to the spring used in this study, and the tube wear depth and volume of our bench tests at $0.1 \mathrm{~N}$ (Table 4) are in the same orders of magnitude as the wear data of the 500-hr assembly test.

Table 4. Wear data for cladding against spring at $0.1 \mathrm{~N}$ for $25 \mathrm{hrs}$.

\begin{tabular}{ccccc}
\hline \multirow{2}{*}{ As-received } & $\begin{array}{c}\text { Max wear depth } \\
(\mu \mathrm{m})\end{array}$ & $\begin{array}{c}\text { Wear volume } \\
\left(\mathrm{x} 10^{-3} \mathrm{~mm}^{3}\right)\end{array}$ & $\begin{array}{c}\text { Wear coefficient } \\
\left(\mathrm{x} 10^{-15} \mathrm{~Pa}^{-1}\right)\end{array}$ \\
\cline { 2 - 5 } & Test 1 & 11.9 & 1.0 & 11.1 \\
\cline { 2 - 5 } & Test 2 & 13.3 & 1.3 & 14.3 \\
\cline { 2 - 5 } Pre-oxidized & Ave & 12.6 & 1.1 & 12.7 \\
\cline { 2 - 5 } & Test 1 & 0.8 & 0.03 & 0.31 \\
\cline { 2 - 5 } & Test 2 & 0.8 & 0.02 & 0.20 \\
\hline \multirow{2}{*}{ Wear ratio (as-received/ Pre-oxidized) } & Ave & 15.8 & $51 \mathrm{X}$ & $51 \mathrm{X}$ \\
\hline
\end{tabular}

Table 5. Wear data for cladding against spring at $0.5 \mathrm{~N}$ for $5 \mathrm{hrs}$. 


\begin{tabular}{ccccc}
\multirow{3}{*}{ As-received } & Test 1 & 14.7 & 5.5 & 60.6 \\
\cline { 2 - 5 } & Test 2 & 12.6 & 3.4 & 37.8 \\
\cline { 2 - 5 } & Ave & 13.7 & 4.5 & 49.2 \\
\hline \multirow{3}{*}{ Pre-oxidized } & Test 1 & 0.8 & 0.01 & 0.12 \\
\cline { 2 - 5 } & Test 2 & 0.9 & 0.03 & 0.35 \\
\cline { 2 - 5 } Wear ratio (as-received/ Pre-oxidized) & 0.9 & 0.02 & 0.23 \\
\hline \multirow{2}{*}{ Ave } & $16.1 \mathrm{X}$ & $211 \mathrm{X}$ & $211 \mathrm{X}$ \\
\hline
\end{tabular}

Table 6. Wear data for cladding against dimple at $0.5 \mathrm{~N}$ for $20 \mathrm{hrs}$.

\begin{tabular}{|c|c|c|c|c|}
\hline & & $\begin{array}{c}\text { Max wear depth } \\
(\mu \mathrm{m})\end{array}$ & $\begin{array}{l}\text { Wear volume } \\
\left(\times 10^{-3} \mathrm{~mm}^{3}\right)\end{array}$ & $\begin{array}{c}\text { Wear coefficient } \\
\left(\mathrm{x} 10^{-15} \mathrm{~Pa}^{-1}\right)\end{array}$ \\
\hline \multirow{3}{*}{ As-received } & Test 1 & 17.3 & 6.3 & 17.5 \\
\hline & Test 2 & 21.5 & 10.1 & 27.9 \\
\hline & Ave & 19.4 & 8.2 & 22.7 \\
\hline \multirow{3}{*}{ Pre-oxidized } & Test 1 & 1.1 & 0.09 & 0.26 \\
\hline & Test 2 & 1.7 & 0.11 & 0.31 \\
\hline & Ave & 1.4 & 0.10 & 0.28 \\
\hline \multicolumn{2}{|c|}{ Wear ratio (as-received/ Pre-oxidized) } & $14.4 \mathrm{X}$ & $80 \mathrm{X}$ & $80 \mathrm{X}$ \\
\hline
\end{tabular}

Table 7. Wear data for cladding against dimple at $2.5 \mathrm{~N}$ for $4 \mathrm{hrs}$.

\begin{tabular}{|c|c|c|c|c|}
\hline & & $\begin{array}{l}\text { Max wear depth } \\
(\mu \mathrm{m})\end{array}$ & $\begin{array}{l}\text { Wear volume } \\
\left(\times 10^{-3} \mathrm{~mm}^{3}\right)\end{array}$ & $\begin{array}{l}\text { Wear coefficient } \\
\left(\times 10^{-15} \mathrm{~Pa}^{-1}\right)\end{array}$ \\
\hline \multirow{3}{*}{ As-received } & Test 1 & 92.4 & 179.0 & 497.2 \\
\hline & Test 2 & 82.6 & 127.0 & 352.8 \\
\hline & Ave & 87.5 & 153.0 & 425.0 \\
\hline \multirow{3}{*}{ Pre-oxidized } & Test 1 & 1.6 & 0.13 & 0.37 \\
\hline & Test 2 & 1.3 & 0.14 & 0.39 \\
\hline & Ave & 1.4 & 0.14 & 0.38 \\
\hline Wear ratio (as & Pre-oxidized) & $60.9 \mathrm{X}$ & $1107 \mathrm{X}$ & $1107 \mathrm{X}$ \\
\hline
\end{tabular}

Table 8. Comparison of wear data reported in the literature.

\begin{tabular}{|c|c|c|c|c|c|}
\hline & & & $\begin{array}{l}\text { Max wear } \\
\text { depth }(\mu \mathrm{m})\end{array}$ & $\begin{array}{l}\text { Wear volume } \\
\left(\times 10^{-3} \mathrm{~mm}^{3}\right)\end{array}$ & $\begin{array}{c}\text { Wear coefficient } \\
\left(\times 10^{-15} \mathrm{~Pa}^{-1}\right)\end{array}$ \\
\hline \multirow{5}{*}{$\begin{array}{l}\text { AECL CANFRET: } \\
\text { transverse motion, } 310 \\
\text { ' } 117 \text { bar, } 200 \text { hrs [18] }\end{array}$} & \multicolumn{2}{|r|}{$0.1 \mathrm{~N}$} & & & 41 \\
\hline & \multirow[t]{2}{*}{$1 \mathrm{~N}$} & Test 1 & & & 4 \\
\hline & & Test 2 & & & 8 \\
\hline & \multirow[t]{2}{*}{$2 \mathrm{~N}$} & Test 1 & & & 0.1 \\
\hline & & Test 2 & & & 0.05 \\
\hline \multirow{3}{*}{$\begin{array}{l}\text { Dongguk assembly: } \\
\text { against spring, } 193{ }^{\circ} \mathrm{C}, 17 \\
\text { bar, } 500 \text { hrs [10] }\end{array}$} & \multicolumn{2}{|r|}{ Spring type-A } & 13.4 & 0.46 & \\
\hline & \multirow{2}{*}{\multicolumn{2}{|c|}{$\begin{array}{l}\text { Spring type-B } \\
\text { Spring type-C }\end{array}$}} & 17.8 & 0.82 & \\
\hline & & & 37.8 & 0.36 & \\
\hline
\end{tabular}


Typical wear scars on the claddings, as-received and pre-oxidized against springs under 0.1 and $0.5 \mathrm{~N}$ load, respectively, are compared in Figs. 4 and 5. Evidently, in either case, the wear scar size on the pre-oxidized cladding is much smaller with substantially less surface damage compared with the as-received cladding, which corresponds well to the wear data in Tables 4 and 5. The wear modes are quite different on the as-received and pre-oxidized surfaces. While the worn surface on the as-received cladding clearly shows features of significant adhesion and plastic deformation similar to literature reports $[12,14]$, the wear mode of the pre-oxidized cladding is dominated by mild abrasion. The wear mode change is attributed to the material composition change (from metallic to oxide) and associated higher hardness (see Table 1).

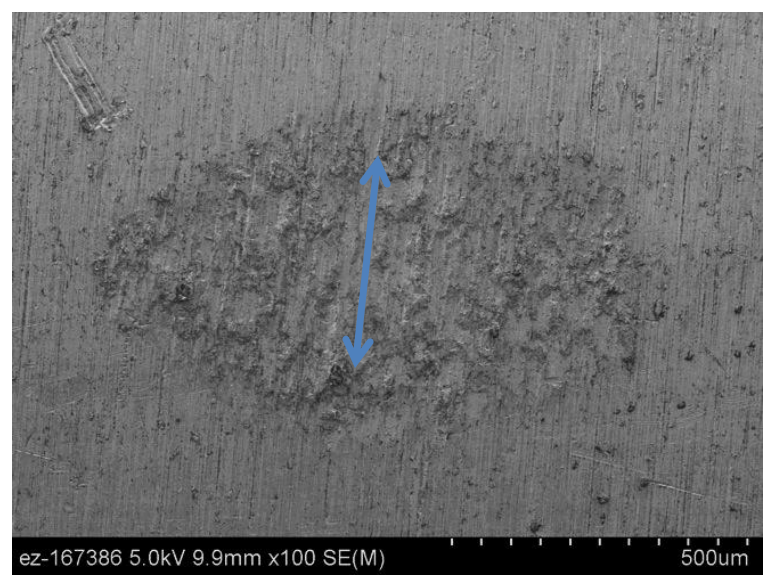

(a) As-received

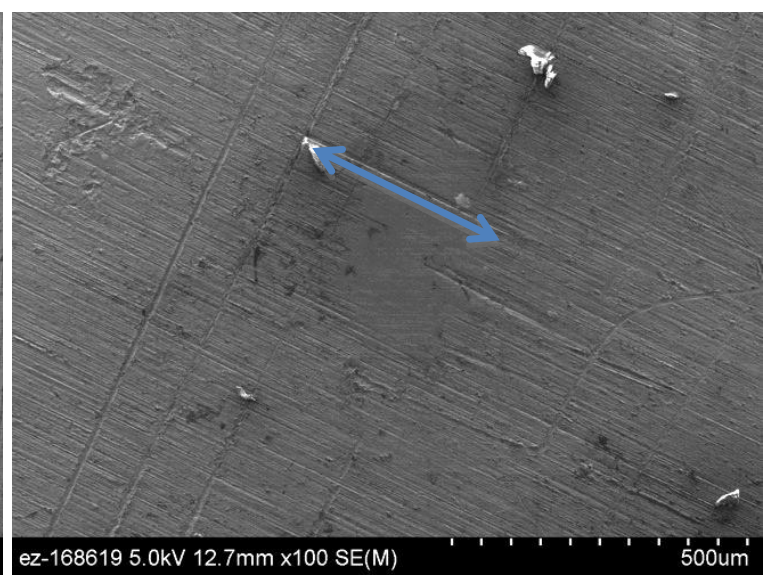

(b) Pre-oxidized 


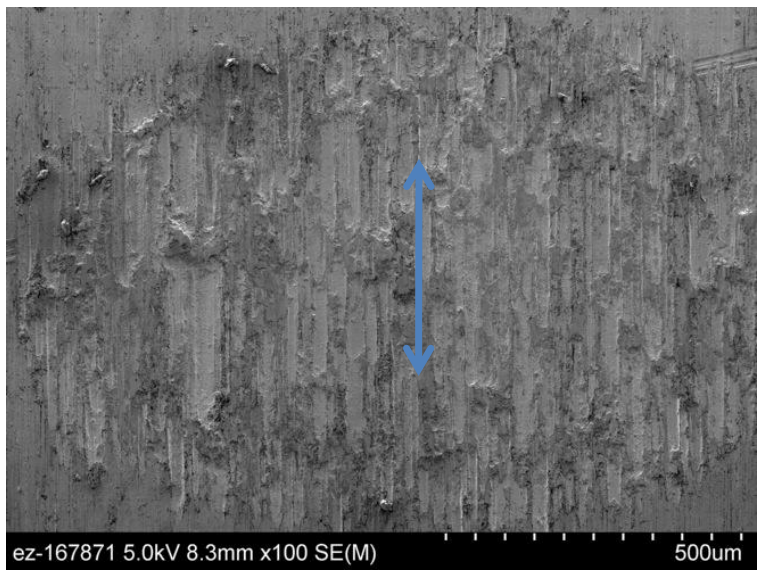

(a) As-received

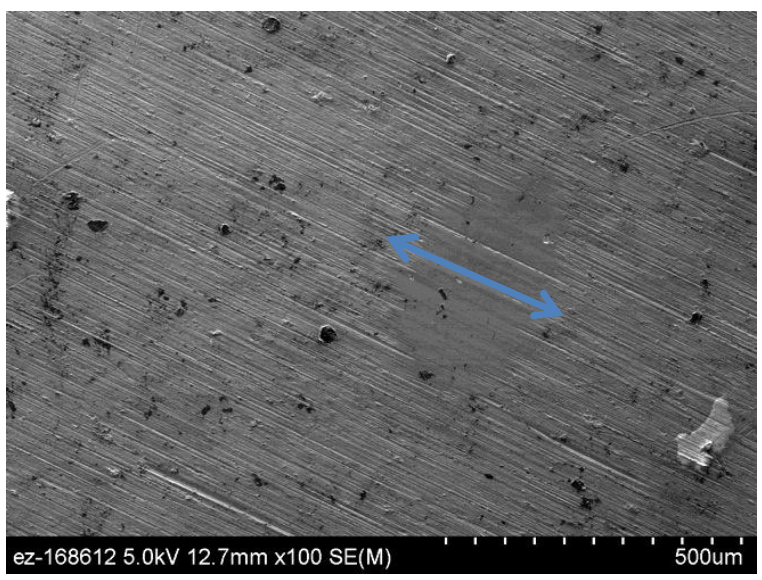

(b) Pre-oxidized

Fig. 5. Wear scars on cladding against spring under a $0.5 \mathrm{~N}$ load (arrows show the oscillation directions).

\section{Wear Model Fitting}

The EWM [15] differentiates itself from a commonly used linear wear model [10] by recognizing a stage-wise wear history, as illustrated in Fig. 6. This oxide film on cladding could be either pre-grown or formed in situ during operation or testing.

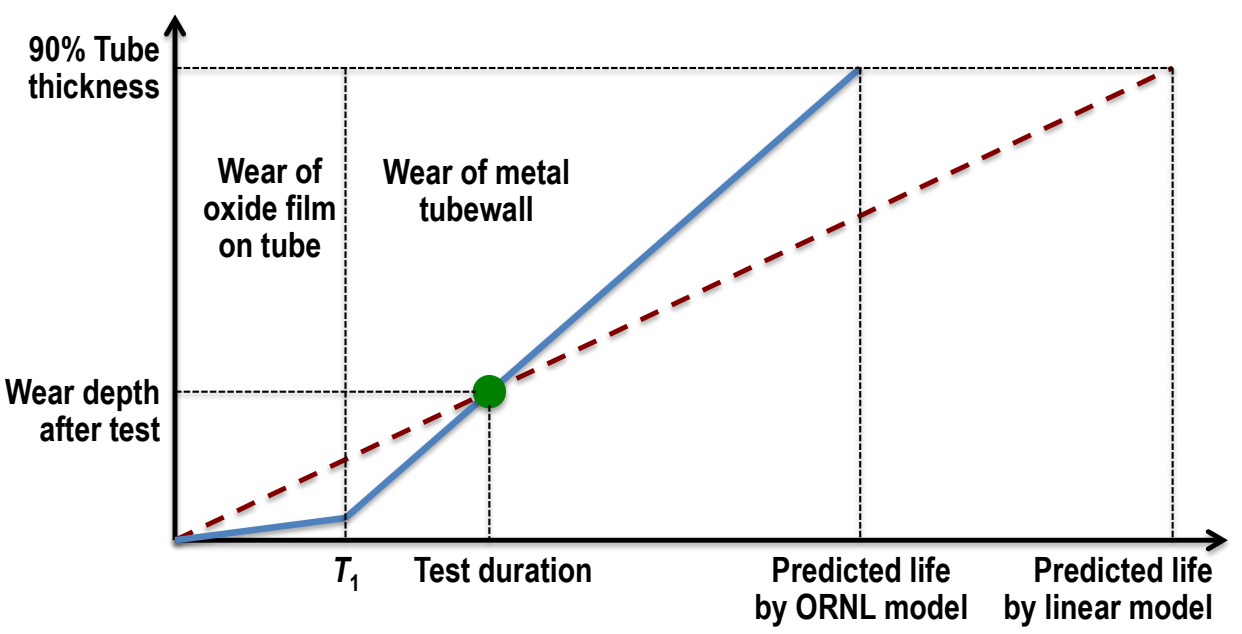

Fig. 6. Comparison of EWM (solid blue line) and linear wear model (dashed red line). 
where $K_{1}$ - wear rate (in depth) of the oxide film (Stage 1 in EWM)

$K_{2}$ - wear rate (in depth) of the alloy substrate (Stage 2 in EWM)

$T_{1}$ - time to wear through the oxide film

$T_{\text {test }}-$ test duration

$T_{\text {life }}$ - time to wear through $90 \%$ of the tube thickness

$T_{\text {life }}$ can be solved by combining Equs. (1-3) to express the EWM by:

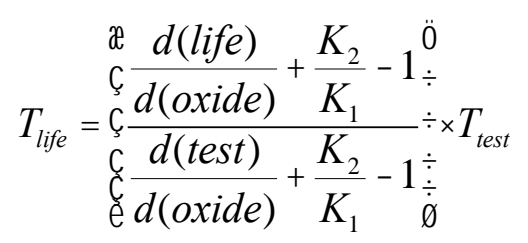

A key factor in Equ. (4) is $\frac{K_{2}}{K_{1}}$, the wear depth rate ratio between the substrate alloy and the oxide film, which is little known in the literature. Our bench fretting test results (excluding the $2.5 \mathrm{~N}$ tests) above suggested a wear depth rate ratio of 15.4 on average.

The Dongguk assembly wear data and in-reactor rod life published in [10] are used as a case study to validate the EWM in the form of Equ. 4. The thickness of the oxide film formed in the assembly test needs to be determined. Motta [19] has reported the oxide growth of Zircaloy-4 in 
$360{ }^{\circ} \mathrm{C}$ pressurized water with an initial rapid rate followed by a much lower rate due to the slow-down of oxygen diffusion through a thicker film. The oxide film thickness was measured to be $\sim 1 \mu \mathrm{m}$ after $500 \mathrm{hrs}$ of static exposure. The Dongguk assembly 500-hr wear tests were conducted in pressurized water at a lower temperature of $193{ }^{\circ} \mathrm{C}$ (slower oxidation) but, on the other hand, the oxide film was instantaneously removed by impact and fretting, which allows fast oxidation of the freshly exposed alloy surface. Considering these two competing factors, we assume the equivalent thickness of the sum of 'short-lived' oxide films formed during the 500-hr process to be $1 \mu \mathrm{m}$. Table 9 summarizes the parameters for predicting the rod life using Equ. 4 .

Table 9. Case study parameters for predicting the rod life using Equ. 4.

\begin{tabular}{ccccccc}
\hline \multirow{2}{*}{$\mathrm{d}($ life) [10] } & \multicolumn{3}{c}{$\mathrm{d}$ (test) [10] } & \multicolumn{2}{c}{$\mathrm{d}$ (oxide) } \\
\cline { 2 - 6 } & Grid type-A & Grid type-B & Grid type-C & $\begin{array}{c}\mathrm{K}_{2} / \mathrm{K}_{1} \\
\text { (Tables 4-6 } \\
\text { above) }\end{array}$ & $\mathrm{T}_{\text {test }}$ [10] \\
\hline $0.57 \mathrm{~mm}$ & $0.0134 \mathrm{~mm}$ & $0.0178 \mathrm{~mm}$ & $0.0378 \mathrm{~mm}$ & $0.001 \mathrm{~mm}$ & 15.4 & $500 \mathrm{hrs}$ \\
\hline
\end{tabular}

Table 10 compares the predicted rod life using the stage-wise EWM (Eq. 4) with the actual in-reactor life [10] and predictions by the literature models based on constant work rate (CWR), constant work density rate (CWDR), and linear work density rate (LWDR) [10]. The CWR and CWDR models tend to over-predict the rod life, while LWDR appears to be an underestimate. In contrast, the stage-wise EWM's predictions fall within the range of field experience.

Table 10. Comparison of predicted rod life (days) by EWM and models in literature.

\begin{tabular}{cccccc}
\hline Grid type & CWR [10] & CWDR [10] & LWDR [10] & In-reactor [10] & EWM \\
\hline A & 3405 & 890 & 136 & n/a & 438 \\
\hline B & 1000 & 670 & 118 & $<500$ & 378 \\
\hline C & 3800 & 350 & 85 & $<500$ & 233 \\
\hline
\end{tabular}


Although results from the initial efforts are encouraging, an on-going challenge for the field of experimental tribology still remains. That is, the test method needs to evolve to better simulate the actual GTRF conditions. Only then will a fair validation of current models like those compared here truly be enabled. Ideally, it would be desirable to test alternative materials and surface treatments for GTRF wear resistance under conditions that simulate exactly the fuel rod bundle contact stresses, motions, coolant flow, frequency, amplitude, chemical surroundings, temperature, and state of irradiation. While for reasons of complexity, radiation safety, and cost, perfect laboratory simulation of GTRF is impractical, there have been a number of notable attempts to improve the simulation of GTRF conditions (e.g. Refs. [20-23]) and at this writing, a new autoclave-based, impact-fretting testing apparatus is being developed to generate more realistic wear coefficients of cladding materials in simulative in-reactor environments.

\section{Conclusions}

The following conclusions derive from the current bench-scale fretting wear experiments designed to provide wear rates for use in testing grid-to-rod fretting models. Pre-oxidation can significantly improves the wear resistance of zirconium claddings. The volumetric wear coefficient of the zirconium oxide layer is 50-200 times lower than that of the non-oxidized alloy. In addition, the linear wear depth rate is $\sim 15$ times less than that of the zirconium alloy substrate. Since actual zirconium alloy claddings in reactor are inevitably oxidized in the hightemperature pressurized water, it is important to treat the wear processes differently for the surface oxide and alloy substrate in modeling GTRF. Using a stage-wise engineering model fitted by experimentally-determined wear rates, the cladding life may be predicted with reasonable agreement with in-reactor experience. 


\section{Acknowledgements}

This research was supported by the Consortium for Advanced Simulation of Light Water Reactors (http://www.casl.gov), an Energy Innovation Hub (http://www.energy.gov/hubs) for Modeling and Simulation of Nuclear Reactors, U.S. Department of Energy. The authors thank Randy J. Parten and William C. Barnhill from ORNL for fretting machine modification and assistance on wear volume quantification, respectively.

Notice: This manuscript has been authored by UT-Battelle, LLC, under Contract No. DEAC05-00OR22725 with the U.S. Department of Energy. The United States Government retains and the publisher, by accepting the article for publication, acknowledges that the United States Government retains a non-exclusive, paid-up, irrevocable, world-wide license to publish or reproduce the published form of this manuscript, or allow others to do so, for United States Government purposes.

\section{References}

[1] ASTM D4170 - 10, Standard Test Method for Fretting Wear Protection by Lubricating Greases, ASTM International - Annual Book of Standards 05.02 (2010).

[2] R. B. Waterhouse, Fretting Corrosion, Pergamon Press, Oxford, UK (1972).

[3] R. B. Waterhouse, ed., Fretting Fatigue, Applied Science Publishers, UK (1981).

[4] R. D. Mindlin, Compliance of elastic bodies in vontact, J. Appl. Mech. 16 (1949) 259-268

[5] M. Godet, The third-body approach - a mechanical view of wear, Wear 100 (1984) 437452.

[6] O. Vingsbo and S. Soderberg, On fretting maps, Wear 126 (1988) 131-147.

[7] D. W. Hoeppner, V. Chandrasekaran, C. Elliott, ed., Fretting Fatigue-Current Technology and Practice, ASTM STP 1367, ASTM International, West Conshohocken, PA, USA, (2000).

[8] M. Varenberg, I. Etsion, G. Halperin, Slip index: a new unified approach to fretting, Tribol. Lett. 17 (3) (2004) 569-573.

[9] R.Y. Lu, Z. Karoutas, T.-L. Sham, CASL virtual reactor predictive simulation: grid-to-rod fretting wear, J. Metals 63 (8) (2011) 53-58. 
[10] K.-T. Kim, The study on grid-to-rod fretting wear models for PWR fuel, Nuclear Engineering and Design 239 (2009) 2820-2824.

[11] R.Y. Lu, M.E. Conner, M.L. Boone, C.L. Wilbur, R. Marshall, Nuclear fuel assembly flowinduced vibration and endurance testing, Proceeding of Symposium on Flow-Induced Vibration - 2001 ASME Pressure Vessels and Piping Conference, July 22-26, 2001, Atlanta, Georgia.

[12] M.H. Attia, On the fretting wear mechanism of Zr-alloys, Tribol. Int. 39 (2006) 1320-1326.

[13] J.G. Han, J.S. Lee, B.H. Choi, W. Kim, G.Y. Tang, Wear and fretting wear behaviour of ion-implanted Zircaloy-4, Surf. Coat. Tech. 83 (1996) 307-312.

[14] L.L. Wang, X. Hu, X. Nie, Deposition and properties of zirconia coatings on a zirconium alloy produced by pulsed DC plasma electrolytic oxidation, Surf. Coat. Tech. 221 (2013) $150-157$.

[15] P.J. Blau, A multi-stage wear model for grid-to-rod fretting of nuclear fuel rods, Wear 313 (2014) 89-96.

[16] A. Pshenichnikov and J. Stuckert (2013), Microstructure and mechanical properties of Zircaloy-4 claddings hydrogenated at temperatures typical for LOCA conditions, online at www.iam.kit.edu/wpt/downloads/Pshenichnikov_QW19_2013.

[17] E.R. Booser, ed. (1997) Tribology Data Handbook, CRC Press, p. 494.

[18] T.P. Joulin, F.M. Guerout, A. Lina, D. Moinereau, Effects of loading conditions and types of motion on PWR fuel rod cladding wear, Paper \#1239, Transactions, SMiRT 16, August 2001, Washington DC.

[19] A.T. Motta, Waterside corrosion in zirconium alloys, JOM 63(8) (2001) 59-63.

[20] H-K. Kim and Y-H. Lee, Influence of contact shape and supporting condition on tube fretting wear, Wear 255 (203) 1183-1197.

[21] M. H. Attia, Fretting fatigue and wear damage of structural components in nuclear power stations - fitness for service and life management perspective, Tribol. Int. 39 (10) (2006) 1294-1304.

[22] S. Okui, Y. Kubo, S. Kakinoki, R. Y. Lu, Z. Karoutas, and T. Ikeno, "Flow-Induced Gridto-Rod Fretting Test and Simulation for NFI PWR Fuel Assembly," ASME, Conference Paper ICONE21-15816 (2013) 7 pp.

[23] V. P. Janzen, N. L. Fisher, B. A. W. Smith, and C.E. Taylor, "Investigations of Fuel-Bundle Motion and Fretting-Wear in the Chalk River Single Channel Test Rig," Proc. $6^{\text {th }}$ Intl. Conference on CANDU Fuel, paper AECL-CONF-01205 (1999) 10 pp. 